\section{"BANGKOK" IN CONTEMPORARY THAI LITERATURE: GLOBALIZATION, TOURISM, AND COMSUMERISM}

\section{Suradech Chotiudompant ${ }^{1}$}

\begin{abstract}
The paper aims to investigate how Bangkok is represented in contemporary Thai literature, including those works by such authors of renown as Chamlong Fangcholachit, Prabda Yoon, and Paritas Hutangkul. Through the perspectives of these contemporary authors, Bangkok has been used as a poignant setting to showcase the problems and conditions of urbanism in Thailand. The paper aims to focus on three main issues of representation, which are not completely separated but closely intertwined: (1) Bangkok as a hub of globalization, where cultural forces, especially those from the West, clash with local knowledge and wisdom; (2) Bangkok as a major tourist destination, where the tourist's imagination of Bangkok and Thailand as an exotic place jars with the realities they actually face upon their arrival; and (3) Bangkok as a city of capitalism and consumerism, where urban people define themselves through their conspicuous consumption. Contemporary Thai literature, especially those works in the last two decades, make manifest the complexity of these three issues as well as
\end{abstract}

${ }^{1}$ Assistant Professor, Department of Comparative Literature, Faculty of Arts, Chulalongkorn University how these issues affect urban dwellers in their everyday life.

\section{Introduction}

It goes without saying that over the past decades Bangkok has expanded both in economic and cultural terms. An increasing number of tourists from all over the world choose Bangkok as both a main tourist destination or as a central point of transit before moving on to neighboring countries such as Laos, Cambodia or Myanmar. Major transnational companies such as Tesco, Boots, McDonalds, and KFC have prospered in this city of angels and the number of incoming companies is on the increase. The presence of this Western influence is jarringly juxtaposed with local places that have lasted for more than a century, such as the Grand Palace, Sanam Luang and major temples in the older part of the city. Exemplary is the case of Khao San Road, which has been a popular haunt for backpackers because it is lined with cheap accommodation and bars that boast big-screen televisions showing a range of English-language programs from Hollywood blockbusters to international football matches. This road, which has been transformed into a walking street frequented by tourists traveling on a shoestring, is so popular that it has featured in several Hollywood films such as The Beach and Hangover II. However, one should also take into account the fact that this road of world renown is located right in the older part of Bangkok, just a stone throw's away from age-old temples, such as Wat Bowonniwet, whose atmosphere of awed sacredness has provided a sanctuary for Bangkokians since King Mongkut was the first abbot in 1836 prior to his 
ascension to the throne (Waugh 1970: Askew 2002 and King 2011). ${ }^{2}$

This juxtaposition is by no means new in contemporary Thai culture and various literary works written by contemporary authors, be they Thai or international, have addressed the multiple forms and dimensions of the East-West encounter by different literary means and with varying perspectives. International authors have extensively fictionalized Bangkok. Figures such as John Burdett, Stephen Leather, Christopher G. Moore and Timothy Hallinan may be little heard of by those studying contemporary literature from the West, but for those in the know, these authors have revisited Bangkok so many times in their fiction. Through their pen (or to be more technologically accurate, their keyboards), Bangkok has been transformed, and to a certain degree stereotyped, into a mysterious, dark place distinguished by dirty alleyways, incredible traffic jams and sleazy bars, peopled by femmes fatales, ghosts, criminals, ladyboys and kick boxers. Their publications can be easily purchased in South East Asian airports and Englishlanguage bookstores in this region. However, this essay aims to focus on a different group of lesser-known literary works, those written by Thai authors, which probably cannot be found except in quality Thai bookstores. Evidently less well known, let alone translated, these contemporary Thai works enjoy only a limited readership. My argument here is that, though being disseminated in a limited circle and little recognized in the international sphere, these works take issue with Bangkok in more different ways than one and more often than not display

\footnotetext{
${ }^{2}$ There have been a number of academic monographs on Bangkok in English.
}

the various perspectives of concerned locals who have seen modernizing changes that have taken place in the capital city and have transformed it into an unfamiliar, uncharted terrain that begs for constant reorientation. Clearly but productively overlapping, globalization, tourism, and consumerism will be three major points around which I will illustrate how Thai authors have addressed these changes.

\section{Globalization and Mobility: Bangkok as an Alienating Place}

Even though there have been arguments that Bangkok has been modernized since the reign of King Mongkut or Rama IV, the process has yet to be completed. Part and parcel of the modernizing process, globalization is a central issue, especially when we consider how Bangkok has been open to international interventions, be they economic, political, or cultural. Encompassing various interdisciplinary issues including economics, political science, and the humanities, globalization is, in my opinion, a useful contextual springboard from which we can effectively discuss the social implications of contemporary Thai literature and explore the degree to which these literary works are concerned with present-day Bangkok's urban conditions.

Globalization is a complex term and various scholars have attempted at a definition. For Malcolm Waters, it is 'a social process in which the constraints of geography on economic, political, social, and cultural arrangements recede, in which people become increasingly aware that they are receding and in which people act accordingly' (Waters 2001: 5). The shifting sense of geography becomes a major issue for Waters, as globalization means a significant improvement in telecommunications 
technology and the aviation industry. We can traverse the world in a shorter span of time and this has changed our perception of space. This reduction in time makes people aware that their 'world' is increasingly smaller in phenomenological terms and this is related to what Roland Robertson calls 'the intensification of consciousness of the world as a whole' (Roberson 1992: 8).

For Anthony Giddens, globalization entails two significant processes: the distanciation or separation of time from space and disembedding. Giddens believes that our contemporary society is different from the premodern one in which space and time were fundamentally linked to our rhythms of daily life. At present, the perception of time and space is no longer an empirical experience, but one that is reliant on the mechanical clock, the timezone system, and global maps (Giddens 1990: 17-21). For Giddens, such a systematization of time and space is part of the modernizing process that translates the whole world, until then perceived as the Tower of Babel, into a rhizomic network of interconnections. This is related to the second process called disembedding, by which Giddens means 'the 'lifting out' of social relations from local contexts of interaction and their restructuring across time and space' (Giddens 1990: 21). Two mechanisms have been instituted to help promote disembedding: symbolic tokens and expert systems. The former means the devising of universal media of exchange, such as the system of currency exchange, and the latter concerns the dissemination and distribution of repertoires of technical knowledge across the globe. These two mechanisms are instrumental in the translation of global complexity and disparity. For these theorists, the world in which we are now living increasingly resembles the 'global village' that Marshall McLuhan prophesied (Carpenter and McLuhan 1970: xi). ${ }^{3}$

Given all these definitions and explications, there must be at least two further remarks: one is that globalization theory should pay more attention to the unequal power relations among nations. Another remark indicates how this inequality generates complex interactions that by no means connote homogeneity in their nature. According to Arjun Appadurai, globalization should not be regarded as the equal and even distribution of global flows, as we may have witnessed from the mushrooming of McDonalds and Starbucks worldwide from Seattle to Beijing, since these flows are in fact disjunctive and multifarious. He argues that:

The new global cultural economy has to be seen as a complex, overlapping, disjunctive order that cannot any longer be understood in terms of existing center-periphery models (even those that might account for multiple centers and peripheries). Nor is it susceptible to simple models of push and pull (in terms of migration theory), or of surpluses and deficits (as in traditional models of balance and trade), or of consumers and producers (as in most neo-Marxist

\footnotetext{
${ }^{3}$ It should be noted here that, despite the term's widespread currency, it was first mentioned, almost in passing, in an introduction to the aforementioned anthology of communication studies, when McLuhan discusses the influence of media, especially television, in creating the effect of simultaneity of event reporting to everyone at the same time, thus transforming the world into a global village.
} 
theories of development). (Appadurai 1996: 32)

Instead of static models presupposing a dichotomy of power relations, Appadurai advances a more dynamic one by distinguishing five different shifting landscapes on which to study global flows: ethnoscapes, mediascapes, technoscapes, finanscapes, and ideoscapes. He goes on to explain that the 'scapes' mean the landscapes of different elements that constitute global culture and these are respectively those of people, technology, capital, media and ideologies/counterideologies (Appadurai 1996: 33-36). In this light, global flows are no longer of a one-way, hegemonic direction but clearly multi-directional and highly sensitive to the landscapes which they pervade.

Bangkok, as an urban space, is susceptible to these global flows. The different landscapes that constitute this capital city manifestly and strongly interact with the global flows in this urban context, as the city space is known to be the one in which global flows are perceptibly more intense than in the countryside. However, despite the theoretical possibilities opened to us by Appadurai, the majority of Thai literary works still take issue with globalization in a unidirectional way, i.e. they portray Bangkok as a receiving end of the global flows and these flows are often addressed in a negative light. An typical example is 'The Witch in the Building' ('Mae Mot Bon Tuek'), a short story by Paritas Hutangkul first published in 1997. Paritas talks about a woman who has relocated from her house in the North to live with her sister in Bangkok. Even though her sister claims that she works as a hairdresser, Muansaikham realizes that her main job is prostitution. However, instead of eyeing her sister askance, she wishes to follow her sister's career path for economic reasons. In portraying Muansaikham's life and aspirations, the author focuses on describing Thailand as a location where Western influence has strongly made itself felt, since the protagonist is aware of such famous international names as 'Andy Warhol' and 'KFC' as well as such local entertainment companies such as 'Grammy' and 'RS', 'thus connoting how she needs to follow the entertainment and fashion industries in order to be regarded as trendy (Hutangkul 2002: 89).

Her migration to Bangkok should be regarded as a movement toward the center in globalized terms, since the capital city is a place where she can immerse herself in these global flows and subsequently be labeled as a sophisticated urbanite. What Paritas suggests here, to use Appadurai's terms, is that Bangkok is a site where all the scapes have received and interacted with global flows with a vengeance. Maunsaikham and other thousands of immigrants like her represent an important ethnoscape that makes Bangkok a hybridized state with pockets of immigrants from different regions, not of Thailand alone but of neighboring countries. The situation is made more complex when we take into account the fact that the mediascapes in this city are used to propagate globalized ideologies of neoliberalism that are often in conflict with long-standing local lores. In this case, Muansaikham finds herself subject to

\footnotetext{
${ }^{4}$ Grammy, now known as GMM, and RS are two giants in Thailand's entertainment industry. They started off in the music industry, introducing new voices in Thai pop music, but now both of the companies have expanded their territories to include TV and radio broadcasting. Grammy, specifically, has recently launched a tour company within its empire.
} 
ideologies such as individualism and the pursuit of wealth, both of which are strongly related to the so-called American Dream, but the institution of such ideologies is not problem-free because the protagonist is also a subject of local beliefs. Hence, it can be construed that Muansaikham is here located at a crossroads, where hegemonic, globalized ideologies are set against local, residual ones. Such an interaction creates feelings of shame and guilt because her aspiration to 'get rich quick' means that she needs to take up prostitution, especially given the limited alternatives for social mobility available to single women in Thailand.

As I have argued elsewhere the form of this short story is extremely important (Chotiudompant 2008: 380-95) and it should be added here that the author intends to present the story of Muansaikham as a parody of L. Frank Baum's Wizard of $O z$. Unlike Dorothy, who is on her way to find the Wizard to help her return to her home in Kansas, Muansaikham needs assistance from the Witch in the Building to 'block' her heart so that she will not feel remorse or guilt with her new-found career. The parallel is so poignant that one feels that the globalized, i.e. hegemonic North American, narrative of Wizard of $\mathrm{Oz}$ is used politically as a critique of globalization, especially when we take into account that the characterization of such an innocent figure as Dorothy is not possible here in Bangkok. Instead of returning to her pristine homeland in the North of Thailand, the protagonist insists on remaining in this urban site where she can prostitute herself.

Globalization in this light brings about a significant flow in ethnoscapes in which an increasing number of people become mobile and, in the case of Thailand, the move is rather towards the metropolis. Like Paritas's 'The Witch in the Building', 'Adrift' ('Khweng') by Tasanawadi also portrays the living conditions of migrant workers in the City of Angels. Like Muansaikham in 'The Witch in the Building', the two protagonists are part of the migrant workers who decide to migrate from their hometowns in the hope of better future. The story, centering on the lives of two Northeasterners or so-called 'Isan' people happening to meet in a karaoke bar in Bangkok, takes place on the night of New Year's Eve. One has been working as a factory worker for five years and the other works as a hostess in the bar. However, the atmosphere on the night of New Year's Eve is eerily quiet as most migrant workers have returned to their home to celebrate the festival with their families. In their opinion, the departure of people from Bangkok during the New Year festival is ludicrous because there are massive traffic jams both on the outbound and inbound journeys and the returnees tend to spend a lot of money throwing parties for their neighbors and fellow villagers. According to the factory worker:

It is getting harder to find hospitality in our hometown nowadays. The villagers will feast on whoever comes back from Bangkok, like buzzards plucking at corpses. If these guests run out of money and walk past their houses, they will be considered worthless. They will be shunned and not invited to eat at the villagers' houses any longer. He can't believe that his hometown which he has left can change this fast. Love and attachments are gradually waning as if they were just superficial illusions. (Tasanawadi 2008: 24) 
For some Thai villagers, people who have been working in Bangkok are regarded as relatively rich and are therefore expected to throw parties. The bigger the parties are, the more highly they will be esteemed. However, even though the two protagonists complain about the mass migration during the New Year festival, the tone of their complaint is tinged with ironic bitterness because they feel they have been left behind in the big city and cannot return to their home simply because they do not have enough money.

In this sense, these two people, until then unknown to each other, share certain sentiments of alienation and loss, as they increasingly feel like strangers both to Bangkok and their hometowns. Replying to his question about whether she misses home, Nid the hostess answers: "Home ... I have a home but I don't feel like I have one. I return home but I don't feel like I have returned to one. My home lost its importance long time ago" (Tasanawadi 2008: 27). Their in-between status and their inability to form a sense of belonging to the place where they live can be seen as a negative consequence of globalization, especially of disembedding. Rendering the issue of distance increasingly irrelevant, disembedding means that traveling and relocation have become increasing commonplace. The popularity of traveling and migration, though on the surface sponsoring the ethics of multiculturalism, also creates a sense of loneliness, as people tend not to stay in one particular place long enough to form their spatial ties.

In 'Khweng', this sense of rootlessness is further radicalized by an attachment to nostalgia and a past that is at once imagined and imaginary. Through Appadurai's mediascapes, both the protagonists try to construct and connect to their roots by frequently referring to look-thung songs, such as 'Like Rice Waiting for a Sickle' ('Muean Khao Khoi Khiew') $)^{5}$ and 'Waiting for Love under the Kradon Tree' ('Ror Ruk Tai Ton Kradon'), ${ }^{6}$ as well as Yaem Yasothon, a recent film about the lives of Northeastern people. However, the last choice is an interesting case, since the film selfreflexively makes use of playful stylization, to the extent that the Northeast is depicted in an ironic way, connoting that our imagine of the Northeast has been both collective and constructed (Rigg and Richie 2002: 359-371). ${ }^{7}$ Although whether or not such an imagine is collective or to what degree it is constructed is of no direct import here but we can discern how much the two protagonists depend on the mass media as a way to construct their homeland so that their rural identity can take root and stand firm against the overwhelming and confusing global flows in the urban space.

Both 'The Witch in the Building' and 'Adrift' portray the living conditions of migrant workers in contemporary Bangkok. The influence of globalization is evident, as all the main characters of these two stories have relocated respectively

\footnotetext{
5 A song originally sung by Ploenpit Phoonthana about a rural woman waiting for a man to return from the city, like rice waiting to be harvested by a sickle.

${ }^{6}$ A song also about waiting as the male singer expresses his sadness upon looking at the Kradon tree in late April. The tree reminds him of the time that he spent with a woman, who has now forsaken him and the countryside for a new life in the city.

${ }^{7}$ It has been argued that perhaps this imagining of idyllic village life in rural Thailand is indispensable and politically related.
} 
from the North and the Northeast in the hope that the metropolis of Bangkok will give them economic opportunities to help with their social mobility. Their dreams and desires are fostered by the globalized image of Bangkok, rife with global flows from all over the world and transmitted through mass media and advertising. However, such a relocation is never an easy task, as in 'The Witch in the Building' where Muansaikham desperately wishes to take up prostitution, which she regards as a shameful job, in order to survive in the city, and as in 'Adrift' where the two rootless protagonists are metaphorically cast adrift in Bangkok.

Even though these two stories reinforce Appadurai's globalization theory in that they illustrate the influence of mediascapes and ethnoscapes and in their contribution to the making of Bangkok as a hybridized space where global flows are seen as rampant, they, by contrast, complicate his theory by showing that what Appadurai (1996) perceives as obsolete, such as the traditional push-andpull and center-periphery models of migration (32), still operates in these two stories. That is, both 'The Witch in the Building' and 'Adrift' signal how Bangkok is still regarded as a place of dreams and desire in the eyes of immigrants, whose locales are depicted as barren or unproductive.

\section{Tourism and Transnational Encounter: Bangkok as a Globalized Place}

If globalization is an umbrella concept that embraces the totality of contemporary conditions, tourism is certainly one of the major pertinent issues. The growth of airline industries and the rise of economy airlines mean that more and more people travel nowadays. According to Löfgren, the industry of tourism has grown steadily since the 1950s and seven per cent of the global workforce was employed in this industry in the mid-1990s (Löfgren 1999: 6). Tourism is one of the most important businesses in Bangkok and Thailand as a whole, as we constantly see the rise of hotels and boutique resorts catering to the increasing number of tourists from around the world.

In theoretical terms, tourism is a form of traveling and involves a certain degree of intercultural communication and interaction. With tourism, Bangkok is transformed into a dynamic space where foreigners meet with local people and this encounter generates a variety of issues that are raised in contemporary Thai fiction. Prabda Yoon's 'A New White Knight in the Heavenly City' ('Atsawin Phew Khao Khon Mai Nai Muang Sawan') directly portrays a white tourist traveling to Thailand and his encounter with the city in various dimensions. Hans, a foreign correspondent assigned to write a story about current political conflicts in Thailand, travels here not only for his job but also to look for the woman he fell in love with two years before when he first came to Bangkok with his wife and two children. Hans believes that their first encounter was fated:

Whilst his family was shopping in a department store, Hans left them to look for a currency exchange kiosk outside. He found one by the roadside and it was there that he met Mai. Standing not far from the kiosk where he changed his euros, she was then not quite twenty years old and had a beautiful Isan look. At first he didn't notice her until he heard her scream and turned his head in her direction. It 
was then that he looked at her face for the first time and she seemed to be in the state of shock. A short, thin man wearing dark glasses and a cap had snatched her bag and had scurried off down the road. Hans tried to chase the snatcher but it was to no avail. The man jumped onto the back of a motorcycle and it had disappeared into the traffic within a few seconds. He panted and walked back to her to offer her his apologies. She thanked him for trying to help and cried in his embrace. They talked for a while and Mai said that she would report the crime to the police but didn't have any money left. Hans gave her a wad of thousand-baht notes and was amazed at himself giving such a lot of money to a stranger. Mai gave him a hug and kissed him lightly on his cheek. Minutes later they went off to make love in an old motel in the vicinity. (Yoon 2012: 48-49)

The lengthy quotation is tellingly symbolic. His first encounter with Mai signifies not just a romantic one on a micro level, but also an unequal power relation between the West and the East on a macro level, with the West represented as a knight in a shining armor giving succor a helpless girl from the East. This can be demonstrated by Hans's dedication to Mai: he returned to Bangkok to see Mai three months later and since then had been sending her money, hoping that it would stop her from prostituting herself and relieve her father from massive debts.

This classic fairy-tale would have had a happy ending if Hans and Mai finally had got married, but Mai lost touch with Hans and the main hidden reason for his latest Bangkok trip was to look for her. His quest for her is unsuccessful and a British man he meets in a bar says that he is a victim of the notorious 'White Knight' syndrome that is spreading especially widely in the group of Western men encountering wretched Third-World prostitutes (Yoon 2012: 50). Disillusioned and heart-broken, Hans is told that Mai is now probably still engaged in prostitution and in a relationship with another rich Western man. The ending of this short story sees the disillusioned Hans finding himself in a similar situation:

Behind him, a woman's scream is audible. Momentarily he stops walking and then decides not to turn back to look. He continues walking. That scream is heard once again; this time there is something fearful and worrying in its tone.

I hope she will be killed, Hans thinks before crossing the road to a brighter side. (Yoon 2012: 51)

The whole situation begs a lot of questions regarding the characters' nobility and victimhood. Is Hans really noble in helping Mai gain a new life, while deserting his wife and two children? Is Mai really a vicious Third-world femme fatale whose seduction and beauty constantly lures Western men to be her prey? Or should we contextualize the whole situation in the landscape of globalization, where the politics of gender and romance is deeply intertwined with the power relations between nation-states?

In this light, Hans's imagination and the 'White Knight' syndrome are part of the East-West encounter that creates a binary opposition between the powerful helper and the powerless victim. To use Edward Said's famous postcolonial framework, this collective imagination can be regarded as part of the Orientalist project in which 
one finds repeated 'some nefarious "Western" imperialist plot to hold down the "Oriental" world' (Said 1979: 12). It goes without saying that such an imperialist plot is firmly embedded in the Western imagination and fosters the 'White Knight' syndrome, since Western men 'naturally' tend to think that Eastern women are in need of help. What complicates the situation is the negotiation of these women, who tend to be aware of this collective imagination and neatly play the role assigned to them. What is important here is not so much whether Mai herself is a victim of the bag snatcher but whether she is aware of the plot and makes use of it. She fits herself perfectly into this role of victim, which she 'needs' to play in order to enhance Hans's nobility as a 'White Knight'. One may think of Mai as a vicious seducer, but Hans's violence, especially the desertion of his family, is smoothly and deliberately glossed over by Prabda's skillful storytelling.

It can be construed here that by depicting both characters thus, the author touches upon the complex relationship between Bangkok and the West in terms of tourism. Hans, in representing the West, is ironically portrayed as a demigod who is ready to "forget" the trappings or attachments that he has in his homeland and emerges as a clean gentleman with no ties whose sacrificial role is overly stressed. Mai, by contrast, represents a Third-World city, readily portrayed as in need of modernization or colonization and the only way she can achieve her agency is through negotiating with the script already prepared for her in the first place. Through Mai, interestingly, Bangkok is no longer a center but a periphery in the wider web of global connections. This peripheral status also means that Bangkok has a limited opportunity to define itself, whilst being violently colonized instead through the process of stereotyping by the West.

While 'A New White Knight in the Heavenly City' focuses on a Western tourist who falls in love with a local woman, Kanthorn Aksornnam's 'Wonders' ('Sing Mahatsachan') does not place emphasis so much on the figure of the tourist as on the influence his perspective has on local people. In this short story, a man who has recently been dumped by his girlfriend finds himself walking around the old city of Bangkok on a Saturday morning. Exploring Sanam Luang, or the so-called Phra Meru Ground, a vast area in front of the Grand Palace reserved for such grand-scale ceremonies as royal funerals and religious festivals, he looks around and marvels at the beauty of the sights before him: small green benches, people doing exercises, small carts selling drinks, pigeons and tiny gardens. These seemingly insignificant props are made even more mystical and surreal when set against the backdrop of the Grand Palace, whose gilded chedi and exquisitely tiled roofs grace Bangkok's morning sky.

However, it is not until he sees a tourist taking a photograph that the protagonist feels he should do the same. At first, the tourist takes photographs of the Grand Palace. Then, he focuses his lens on a homeless person sleeping on a bench. Inspired by the tourist, the protagonist follows suit and starts taking photographs of various objects around him: the homeless, a pigeon, an ornate pavilion carefully built to house a royal funeral and a stage prepared for a political gathering. He then has a chance to talk to the tourist: 
I say to him: 'Hello. Are you doing all right?'

He replies: 'Of course. I like Bangkok. It is marvelous.'

The Western man is tall and thin, his hair cleanly cropped with scattered white hairs. In fact, they are rather grey. I ask him: 'Do you like taking photographs?' He answers: 'Yes, of course. There are a lot of things to photograph here. I like taking photographs of people in different places. And you?'

I laugh and then answer: 'There are a lot of things to photograph anywhere. I like taking photographs of people, both alive and dead.' (Aksornnam 2010: 173)

Photography is no longer a hobby in this short story but a significant act, especially in terms of memory and spatial orientation. Susan Sontag convincingly argues that 'as photographs give people an imaginary possession of a past that is unreal, they also help people to take possession of space in which they are insecure. Thus, photography develops in tandem with one of the most characteristic of modern activities: tourism' (Sontag 2005: 6). Taking Sontag's cue, both the tourist and the local man are both insecure: whilst the tourist is outside his own country, thus feeling insecure spatially, the young Thai man dumped by his girlfriend is spiritually insecure and needs to reorient his life now that he is on his own. Therefore, it is no wonder that both of them need to take photographs as photography has become a way in which both of them can take possession of, or reconnect with, the complex world they are encountering.

Sontag begins her book by powerfully suggesting that 'to collect photographs is to collect the world' (Sontag 2005: 1) and one can see that the characters in this short story reinforce her argument. Tourism in this sense means to travel afar to gain a fresh perspective through photography and ironically the local man has learnt this from a tourist. It also reminds him of how he once videotaped the naked body of his ex-girlfriend. Even though the video only lasts for seconds, he thinks that 'her body is one of the world's marvelous objects' (Aksornnam 2010: 179). Now that he realizes how important photography is, his videotape of her naked body remains an important life-saving souvenir for him, an object that can forever lead him back to her.

The ending sees the young man remember the tourist wearing a t-shirt that says 'Not So Black and White' and he thinks that he should have all the photographs that he has taken developed in black and white, except for those of the royal funeral pavilion and those of his girlfriend's naked body. What links the two things together is transience: the pavilion will be dissembled once the funeral finishes whilst his ex-girlfriend is no longer in the relationship with him. In comparison to these photographs that will remain colorful in his heart, other photographs of Bangkok will be in black and white since they remain the same, acting like the backdrop against which love and death play their part in contemporary urban life. In this short story, Bangkok is represented as an ageold city, a black-and-white platform where countless tragedies and comedies of people have been staged for hundreds of years. However, what is significant is that this city is vivified by deaths and attachments taking place in its precincts. Tourism, in this sense, is a means by which the locals learn to appreciate the city from a new set of lens, as the author 
expands the definition of the tourist to include not only a foreigner coming into a country but also a local who marvels at his or her own country from a renewed stance.

Through tourism, Bangkok in both 'A New White Knight in the Heavenly City' and 'Wonders' is represented as a multilayered city related to love and loss. For some white men including Hans in the first short story, Bangkok is the place where they fall in and out of love, disillusioned with dangerous, yet alluring Thai women. For some locals like the anonymous protagonist in 'Wonders', tourism means an interaction with a new perspective and eventually the ability to shift to a new way of understanding life and transience. Despite being heart-broken, he is able to learn that his own drama is only a minute part that constitutes Bangkok, but the raw feelings and emotions captured in his photographs do turn Bangkok from a colorless backdrop into such a lively space.

\section{Consumerism and}

\section{Commodification: Bangkok as a Capitalist Place}

Closely connected to the issues of globalization and tourism, consumerism is part and parcel of capitalism. Raymond Williams argues that the word 'consume' dates from the fourteenth century when its meaning was negative since it was used to mean to use up, to waste and to squander. The word 'consumption' in the old days was a name of any wasting disease before it was used to specifically denote severe pulmonary tuberculosis. However, from the mid-nineteenth century onward, the word was used neutrally in bourgeois political economy (Williams 1976 78-79). While consumption refers to a general act of using up and spending, consumerism is a specific way of consumption that is related to capitalism, in which people are encouraged to spend money on objects, not just for their use value but also for exchange and symbolic values (Aldridge 2003: 2). According to Jean Baudrillard, we no longer consume objects as such, but what they mean, i.e. the signifier. In his words, what we consume is:

no longer a sequence of mere objects, but a chain of signifiers, in so far as all of these signify one another reciprocally as part of a more complex super-object, drawing the consumer into a series of more complex motivations. (Baudrillard 1998: 27)

What Baudrillard points at is a worrying trend that capitalism has inflicted on the general public, especially more acutely on urban people. Consumerism in this sense not only means an addiction to shopping to the extent that it is elevated to an indispensable ritual of everyday life but also the values and beliefs that people form around such an act of consumption. In other words, objects we consume will be judged against us: our bag, our car, our clothes, our mobile phone, and so on.

With its status as the capital of Thailand for more than two centuries, Bangkok has opened itself to capitalism and consumerism. Shopping centers have mushroomed in this city of angels, ranging from the high-end Paragon to the world's biggest open-air market of Jatujak, and it goes without saying that one of the most popular hobbies of Bangkokians is shopping. Contemporary Thai literature also focuses on consumerism in the city space of Bangkok and one of these is 'Adrift in the City (Siam Square Studio)' ('Khweng Khwang Klang Nakhorn (Studio Siam Square)') by Chamlong 
Fangcholachit, a veteran Thai author. The setting of this short story is based on the real geographical space of Siam Square, a vast shopping area in the city center near the Siam Interchange Station of the Bangkok sky train system. Siam Square is used as a symbolic space of consumerism in the story and the author clearly divides the area into two parts: a real space and an imaginary one. In the first part, the protagonist walks into Siam Square to wait for his girlfriend and the author here refers to such real places as a bus stop opposite the Mah Boonkrong Center (MBK), a world-renowned shopping center, and the Hard-Rock Café, located right inside Siam Square. As the protagonist has not visited Siam Square for a long time, he is surprised by how much the area has changed, especially the ways in which teenagers loitering in the area dress themselves:

Hundreds of characters aged from 14 to 17 years old walk past each other, their left hands holding the latest models of mobile phones, their right hands carrying school bags. No one walks empty-handed. Almost everyone carries a bag in which one can find his or her latest purchases. They window-shop clothes and shoes. Their hair is deliberately disheveled with some covering their ears and face. If one doesn't listen to their talk, one may not be able to perceive whether they are from Thailand, Japan, Hong Kong, Taiwan, or South Korea. From their tone and gesture, one may also clearly discern whether they are male, female, or half-male and half-female. "It's no longer our Siam Square here." (Fangcholachit 2011: 14)
In addition to those teenagers whose ways of dressing, talking, and walking are so distinct from the old days, the physical aspect of Siam Square has also changed significantly. The establishment of the Paragon Shopping Center and the Sky Train system, both of which are located directly on the northern side of Siam Square, has transformed the space into one of the most popular meeting points for Bangkok residents and tourists alike.

The ways in which Siam Square has changed beyond the protagonist's recognition amaze and confuse him. When the protagonist enters a coffee shop and waits for his girlfriend, he is stared at as if he were from another world. It is no wonder that he feels angry and leaves the coffee shop. This is the start of his journey into 'the parallel world' of Siam Square, an imaginary, upside-down universe that pushes the capitalist logic to the extremes. First, he finds himself wandering in an alleyway where it is getting darker. Before long, he meets some strange wonders: a talking rat, a parking lot transformed into a flea market selling such impossible or unimaginable objects as the third-page paper, time, shadows, dreams and honesty. The protagonist is willing to give a deposit of 100,000 Baht to buy 'a dream' even though he has yet to see what it actually is. In addition, to purchase 'happiness', he pays as much as 10,000 baht. It is not until he has finished the transactions in the surreal flea market that it dawns on him that he has forgetten to call his girlfriend. $\mathrm{He}$ is even more surprised when he looks at his mobile phone and realizes that he has nine missed calls and that he has not heard any of them (Fangcholachit 2011: 29). What this connotes is the fact that he is so engrossed in shopping that he has forgetten his other relationships and this is probably what the author wants to critique: 
we embrace consumerism at the expense of human communication.

Besides, such surreal transactions also point toward the logic of commodification, in which not only a range of objects but also certain beliefs or values can be commodified, since the purchase of certain objects can be related to the possession of certain desirable traits. Nowadays some people show their love by buying roses for someone they love and some men smoke cigarettes to flaunt their masculinity. With such logic, people with more money have more options available to them and this in turn helps with their social mobility when they can assume so many roles and acquire not just objects but experiences to enhance their lifestyle. However, what the author here wishes to critique is perhaps this type materialistic world view in which everything is reduced to money, especially now that money can buy objects and objects in their turn can lead to certain values and feelings, especially happiness and dreams.

The ending of this short story is therefore telling when he meets the talking rat once again on his way back. She asks him whether he is interested in buying musical notes:

"Musical notes?" he repeats.

"Yes, musical notes. They were found under the staircase here."

"Apparently you didn't seem to put any investment in your business, Miss Black-Market Seller."

The young rat's laughter is crisp. "I don't want them to be left lying under the staircase and rotting in the soil." (Fangcholachit 2011: 33)

However, when he allows her to give him a peck on his cheek, the rat decides not to sell the notes, but gives them for free. It transpires that the notes are part of the famous song 'Auld Lang Syne', which is poignantly used here to denote the spirit of friendship that transcends worldly matters, including in this case consumerism. Even though the poor rat has found an opportunity to sell her goods, she decides not to. Even though she does not earn any money in return, her generosity melts the protagonist's heart, as he is visibly touched by her friendship and generosity.

While Chamlong uses magical elements to portray the logic of consumerism, Pad Pasikorn uses humor to underline similar issue in his short story, 'Outdoor, the Slender Type' ('Outdoor, Pan Sa-od') (Pasikorn 2009). Pad's protagonist has just bought a 4WD because of to the image the vehicle projects. He first saw and fell in love with the vehicle when it was showcased in a fake jungle in a shopping mall, thereby projecting the image of the driver as someone who is tough, masculine and adventurous. Also, he was attracted to its brochure, which has the vehicle "parked sternly in the forest, by a stream and an intimidating waterfall. Sunlight gleams through leaves in various thick and thin rays, some of which penetrate the vehicle's windshield seeing its full load. Tied on top of the vehicle is an orange kayak whose side runs parallel with the vehicle' (Pasikorn 2009: 13). However, after owning the vehicle, he dare not drive it, not for fear of rain or road hazards, but because he thinks that his personality is so different from that of the vehicle: in his opinion, he is too 'immaculate'. He thus spends a month improving his character, buying new clothes and having new haircut, changing his watch as well as having his body pierced to create a rugged masculine look. 
However, as the story progresses, he does not use his new 4WD in the forest as he first imagined and intended, but as a normal car that transports him to work and back home in a city full of traffic jams. One of the limited occasions when he can use his vehicle nearest to its 'projected' image is when he needs to take his dog, a Siberian husky, to see a veterinarian. Another occasion arises when he needs to drive his vehicle to help his girlfriend from her house, which is badly affected by flooding. After two years of owning the vehicle, he feels proud since it is fearless in face of the floods. Tied to its top is not an orange kayak as appeared in the brochure but a fiberglass boat.

What this story reveals through its humor is how much the protagonist, being typical of middle-class Bangkok residents, falls prey to consumerism. Through fantasy and the innocent belief in images projected through advertising and to the mass media, the protagonist spends two million Baht on a vehicle that ironically does not function to its utmost potential in the urban space of Bangkok. He imagines himself to be an adventurous Indiana-Jones-like hero trekking the forest but in reality he is a regular office worker. Consumerism here is a means of escaping his humdrum life, because owning a $4 \mathrm{WD}$ plays a significant role in helping him to create an alternative identity. However, one also sees how influential the vehicle is on him, since he needs to change himself to fit the image of the 4WD driver, to the extent that the logic of consumption is now reversed: instead of owning the objects, we are in fact 'owned' by the objects and their constructed images. Hence, it is not too far-fetched to conclude that we become slaves to the objects that we own and need to tailor our lives in relation to them. In this story, Bangkok becomes a consumer society where objects and their related images are so powerful that they exert their influence on the lifestyle of city people.

In both 'Adrift in the City (Siam Square Studio)' and 'Outdoor, the Slender Type', we can see how Bangkok has been portrayed as a consumer society in which the logic of consumerism can be strongly felt. Not only are people attracted to the commodification of certain values and beliefs, such as dreams and happiness, hoping to have a short cut to their ideal life in 'Adrift in the City (Siam Square Studio)', they are also mesmerized by imported objects, such as a 4WD vehicle in 'Outdoor, the Slender Type' and use these objects increasingly because of their symbolic status not their real utility. The power of the mass media in creating symbolic meaning for these objects cannot be clearer: the brochure, the television commercial, or even the promotion staged in a shopping mall all contribute to the images firmly engraved on people's minds. In this light, one can see that, with such a complex system of consumerism, Bangkok is clearly a global city, not only in the sense that goods come from various countries all around the world but also in the sense that the way we consume is increasingly similar to the way the rest of the world does, i.e. through mass media spinning and adherence to symbolic value.

\section{Conclusion}

From various short stories written by Thai authors over the last two decades, one can discern the complex images of contemporary Bangkok, a city that is now part of the planetary network of international connections. What is interesting is the fact that not only is Bangkok portrayed as being perched on the receiving end of global flows, the 
characters, especially the locals, are, to an extent, rendered as powerless in their resistance to these flows. In other words, the reaction on their part is either disconsolate submission to the consequences of globalization with no clear solution in sight, such as those migrants in 'Adrift', bitter self-loathing humor as in 'The Witch in the Building' or escapist fantasy as in 'Adrift in the City (Siam Square Studio)'. In this light, the function of these stories is to expose the reader to the mechanisms of globalization, rather than to offer ways to redress injustices and exploitation engendered by such mechanisms.

In a nutshell, from the perspectives of these authors, Bangkok is no longer an idyllic capital, serene and made exotic by local culture, but a multi-layered, heterogeneous city where locals, expatriates, tourists and immigrants all live together and interact on a daily basis. Their interactions are not as smooth as silk as found in contemporary mass media targeted on incoming tourists but are complicated by unequal and unidirectional global flows, expectant normative narrative forms, such as the civilized knight and the barbarous victim, and global consumerist logic. Though disseminated to a limited circle of readers, these stories make manifest human interactions and feelings that are enacted and re-enacted in the vast, sublime landscape of Bangkok. Not only do they portray the difficulties, anxieties, loves and losses befalling people in Bangkok in this globalized age, they, in turn, also bring Bangkok to life and reinforce the image of the city as a daunting yet alluring metropolis.

\section{References}

Aksornnam, Kanthorn. 2010. 'Sing Mahatsachan', in her Freshkills and Other Stories (เฟรชคิลส์ และการเดินทางขอ เรื่องราวอื่น). Bangkok: Pajonphai. (In Thai)

Aldridge, Alan. 2003. Consumption. Cambridge: Polity.

Appadurai, Arjun. 1996. Modernity at Large: Cultural Dimensions of Globalization. Minneapolis: University of Minnesota Press.

Askew, Marc. 2002. Bangkok: Place, Practice and Representation. London and New York: Routledge.

Baudrillard, Jean. 1998. The Consumer Society: Myths \& Structures. London: Sage.

Carpenter, Edmund and Marshall McLuhan, eds. 1970. Explorations in Communication. London: Cape.

Chotiudompant, Suradech. 2008. 'Thai Magical Realism and Globalization', in Terence Chong, ed. Globalization and Its Counter-Forces in Southeast Asia. Singapore: ISEAS.

Giddens, Anthony. 1990. The Consequences of Modernity. Cambridge: Polity.

King, Ross. 2011. Reading Bangkok. Singapore: NUS Press.

Hutangkul, Paritas. 2002. "Mae Mod Bon Tuek." Mae Mod Bon Tuek. Bangkok: Rubchan. 
Löfgren, Orvar. 1999. On Holiday: A History of Vacationing. Berkeley: University of California Press.

Fangcholachit, Chamlong. 2011. "Khweng Khwang Klang Nakhorn (Studio Siam Square)." Phom Kab Phom Ik Khon (Kham Hai Phon Hub Haew Hang Khwam Kliat Chang (ผมกับผมอีกคน (ข้ามให้ พ้นหุบเหวแห่งความเกลียดชัง)). Bangkok: Rubchan. (In Thai)

Pasikorn, Pad. 2009. "Outdoor, Pan Sa$\mathrm{Od}$ " (เอาท์ดอร์ พันธุ์สะโอด). Sam Neang Khong Wela (สำเนียงของเวลา). $2^{\text {nd }} \mathrm{ed}$ Bangkok: Kanetburi. (In Thai)

Rigg, Jonathan and Mark Richie. 2002. "Production, Consumption and Imagination in Rural Thailand." Journal of Rural Studies. 18.4:359-371.

Robertson, Roland. 1992. Globalization. London: Sage.

Said, Edward. 1979. Orientalism. New York: Vintage.

Sontag, Susan. 2005. On Photography. New York: Rosetta Books.

Tasanawadi. 2008. "Khweng" (เคว้ง). Moo Ban Aerobic (หมู่บ้านแอโรบิก). Bangkok: Praew Publishing. (In Thai)

Waters, Malcolm. 2001. Globalization., $2^{\text {nd }}$ ed London: Routledge.

Waugh, Alec. 1970. Bangkok: The Story of a City. London: W. H. Allen.

Williams, Raymond. 1976. Keywords: A Vocabulary of Culture and Society. London: Fontana.
Yoon, Prabda. 2012. "Atsawin Phew Khao Khon Mai Nai Muang Sawan” (อัศวินผิ ขาวคนใหม่ในเมืองสวรรค์) DaoDuek Damban (ดาวดึกดำบรรพ์). Bangkok: Typhoon. (In Thai) 